\title{
KAJIAN KOMPARATIF PENGEMBANGAN EKOWISATA BAHARI VERSUS PENANGKAPAN IKAN DI PERAIRAN PULAU KOON - MALUKU
}

\author{
Oleh \\ M. Agus Sutiarso \\ Sekolah Tinggi Pariwisata Bali Internasional
}

A.A. Putu Swabawa

Politeknik Negeri Bali

\begin{abstract}
This research was conducted in the district of Pulau Gorom, East Seram Regency, Maluku, in the context of developing marine ecotourism in the Koon Island Ocean. Data collection is done using interview and literature study methods. The analysis technique uses benefit-cost ratio analysis, in addition to using qualitative analysis techniques. From the analysis results show that the Koon Island Ocean deserve to be developed into marine ecotourism, because the benefit-cost ratio is two times greater than the benefit-cost ratio for traditional fishing. The tourism sector has advantages with other sectors mainly in the form of labor intensive and tourism sector margins far higher than other economic sectors.
\end{abstract}

Keywords : marine ecotourism, traditional fishing, Koon Island Ocean

\begin{abstract}
ABSTRAK
Penelitian ini dilakukan di kecamatan Pulau Gorom kabupaten Seram Bagian Timur, Maluku, dalam rangka pengembangan pariwisata bahari di perairan pulau Koon. Pengumpulan data dilakukan dengan menggunakan metode interview dan studi pustaka. Teknik analisis menggunakan analisa benefit-cost ratio, disamping menggunakan teknik analisa kualitatif. Dari hasil analisa menunjukkan bahwa perairan pulau Koon layak dikembangkan menjadi ekowisata bahari, karena benefit-cost ratio-nya dua kali lipat lebih besar dari benefit-cost ratio untuk penangkapan ikan. Sektor pariwisata mempunyai keunggulan dengan sektor lainnya terutama bersifat labor intensive dan margin sektor pariwisata jauh lebih tinggi dari sektor ekonomi lainnya.
\end{abstract}

Kata kunci: ekowisata bahari, penangkapan ikan, perairan pulau Koon

\section{PENDAHULUAN}

Daerah Seram Bagian Timur merupakan sebuah kabupaten seluas $\pm 20.656,894 \mathrm{~km}^{2}$ terdiri dari luas laut $14.877,771 \mathrm{~km}^{2}$ dan luas daratan $5.779,123 \mathrm{~km}^{2}$. Terbagi dalam 8 (delapan) Kecamatan. Daerah ini memiliki banyak potensi wisata, utamanya gugusan pulaupulau yang berpasir putih dengan keindahan terumbu karang di perairannya dan kekayaan ikannya, sangat cocok untuk dikembangkan menjadi ekowisata bahari. 
Pulau Koon merupakan pulau kecil tanpa penduduk yang terdapat di Kecamatan Pulau Gorom kabupaten Seram Bagian Timur. Selain potensi terumbu karang yang beraneka ragam, di perairan Pulau Koon dapat dijumpai sebuah atraksi menakjubkan dimana ikan berkumpul dalam jumlah yang banyak untuk melakukan pemijahan. Untuk melestarikan fenomena ini, WWF Indonesia berinisiatif melindungi kawasan ini demi ketersediaan sumberdaya ikan untuk masa mendatang. Dibuatlah kesepakatan konservasi laut (Marine Conservation Agreement) antara masyarakat adat Gorom yang diwakili oleh Raja Kataloka dengan WWF Indonesia.

Dengan dilakukan konservasi (perlindungan) terhadap eksistensi perairan pulau Koon ini, maka ada aturan yang diterapkan oleh penguasa atau raja Kataloka berupa larangan untuk menangkap ikan di sekitar pulau Koon. Dengan diberlakukannya aturan ini maka pendapatan nelayan mengalami penurunan setengah dari pendapatan yang diperoleh sebelum aturan ini ditetapkan. Ini berarti nelayan kehilangan pendapatan setengah dari pendapatan sebelumnya yang menyebabkan terjadinya opportunities lost dalam perekonomian di kecamatan Pulau Gorom, karena para nelayan yang melakukan penangkapan ikan di perairan Pulau Koon berasal dari pulau Gorom. Untuk mengatasi dampak dari konservasi di perairan pulau Koon tersebut, maka ada rencana dilakukan pengembangan ekowisata bahari di perairan pulau Koon dan sekitarnya. Untuk efektifitas pengembangan ekowisata bahari di sekitar perairan pulau Koon, maka perlu mempertimbangkan manfaat yang diperoleh dan biaya yang dibebankan dalam pengembangan pariwisata tersebut dibandingkan dengan manfaat dan biaya yang terjadi dalam penangkapan ikan yang dilakukan oleh para nelayan di pulau Koon dan sekitarnya.

Penelitian ini akan mengkaji benefit cost ratio (perbandingan manfaat dengan biaya) antara rencana pengembangan ekowisata bahari (diving, snorkeling, sightseeing) dengan penangkapan ikan yang dilakukan oleh para nelayan di perairan pulau Koon dan sekitarnya, dalam rangka mengetahui layak tidaknya wilayah sekitar perairan Pulau Koon dikembangkan menjadi ekowisata bahari.

\section{METODOLOGI}

Metode yang digunakan dalam pengumpulan data adalah dengan melakukan observasi, survey dan wawancara kepada para nelayan, pengusaha ikan, pemuka masyarakat kecamatan pulau Gorom, dan kepala Dinas Pariwisata dan Perikanan Kabupaten Seram Bagian Timur.

Teknik analisa data yang digunakan adalah dengan menghitung Benefit cost ratio dengan rumus (Jumingan, 2009):

\section{B/C Ratio $=\sum \mathbf{P V}$ ( positif ) : Io}

$\sum \mathrm{PV}($ positif $)=\mathrm{CF} \times(\mathrm{PVF}$ tn $)$

$\mathrm{CF}=$ Aliran kas yang bernilai positif pada periode $\mathrm{t}$

Io = Modal awal Investasi

Selain dengan teknik kuantitatif tersebut, analisa juga dilakukan secara kualitatif dibantu dengan studi pustaka untuk mengambil kesimpulan. 


\section{HASIL DAN PEMBAHASAN}

\section{Aktivitas Penangkapan Ikan di Perairan Pulau Koon}

Pulau Koon merupakan salah satu pulau tidak berpenghuni dari gugusan pulau-pulau kecil yang terletak di kecamatan Pulau Gorom. Di sekitar pulau Koon ada pulau Panjang, pulau Grogos, pulau Nukus, dan pulau Neding. Di perairan pulau Koon selama ini merupakan tempat ikan-ikan memijah. Sering dijumpai segerombolan ikan berkumpul melakukan parade yang sangat fantastik, jarang ditemui di daerah lain. Kondisi ini merupakan sebuah fenomena alam satwa ikan yang perlu dilestarikan. Disamping mempunyai potensi yang sangat prospektif untuk dikembangkan menjadi objek ekowisata bahari berupa diving. Melihat fenomena ini, maka pihak WWF terpanggil dan mulai melakukan konservasi terhadap keberadaan perairan Koon ini dalam rangka keberlanjutan sumberdaya perikanan. Melalui kesepakatan yang dilakukan antara WWF dan masyarakat adat untuk melindungi wilayah tersebut, maka penguasa atau raja Kataloka yang menaungi wilayah tersebut mengeluarkan aturan untuk melarang para nelayan menangkap ikan di sekitar pulau Koon tersebut. Dengan adanya larangan tersebut pendapatan nelayan mengalami penurunan setengah dari hasil penangkapan sebelum adanya aturan tersebut, karena nelayan menangkap ikan di perairan yang lebih jauh. Para nelayan yang menangkap ikan di perairan pulau Koon tersebut berasal dari pulau Gorom, dimana di pulau Gorom terdapat 16 kelompok petani nelayan dan masing-masing kelompok terdiri dari 20 orang nelayan, disamping terdapat 6 perusahaan penangkap ikan. Jumlah penduduk pulau Gorom sebanyak 27.285 jiwa dengan jumlah rumah tangga sebanyak 4.874 rumah tangga. Dimana komposisi penduduknya 13.742 orang laki-laki dan 13.543 orang perempuan.

Selama satu tahun para nelayan hanya bisa melaut selama 6 bulan dan setiap bulan melaut sebanyak 15 kali karena keadaan cuaca. Sedangkan hasil tangkapan setiap kali melaut adalah sebagai berikut:

Tabel 1

Hasil Tangkapan Ikan Sekali Melaut

\begin{tabular}{|c|c|c|c|}
\hline \multirow{2}{*}{ No. } & \multirow{2}{*}{ Jenis Ikan } & \multicolumn{2}{|c|}{ Hasil tangkapan ( Kg / Ton ) } \\
\cline { 3 - 4 } & & $\sum$ Maksimal (Kg) & $\sum$ Minimal (Kg) \\
\hline 1 & Ikan Tuna & 40 & 25 \\
\hline 2 & Ikan Tenggiri & 30 & 10 \\
\hline 3 & Ikan Cakalang & 20 & 15 \\
\hline 4 & Ikan Bubuhan & 15 & 5 \\
\hline 5 & Ikan Kakap merah & 20 & 10 \\
\hline
\end{tabular}

Sumber: Nelayan

Biaya yang dikeluaran dalam sekali melaut, meliputi:
a. Bensin + Oli
Rp. 200.000,-
b. Umpan
Rp. 150.000,-
c. Bekal
Rp. 50.000,-

Sedangkan biaya modal yang dikeluarkan berupa :
a. Kapal perahu
Rp. 10.000.000,- 

b. Speed Mesin
Rp. 20.000.000,-
c. Pancing
Rp. 2.000.000,-
d. Tali
Rp. 60.000,

Tabel 2

Harga Ikan di Pasar Lokal

\begin{tabular}{|c|l|c|}
\hline No. & Jenis Ikan & Harga ( Rp ) \\
\hline 1 & Ikan Tuna & 5.000 \\
\hline 2 & Ikan Tenggiri & 5.000 \\
\hline 3 & Ikan Cakalang & 4.000 \\
\hline 4 & Ikan Bubat & 4.000 \\
\hline 5 & Ikan Kakap Merah & 10.000 \\
\hline
\end{tabular}

Sumber: Nelayan

Sedangkan perusahaan penangkap ikan selama satu tahun melaut juga selama 6 bulan, namun setiap bulan hanya melaut 12 kali, di mana setiap kali melaut mendapatkan hasil ratarata sebesar Rp. 4.000.000,- dengan biaya operasional sebagai berikut:

Tabel 3

Biaya Operasional Melaut Perusahaan Penangkap Ikan

\begin{tabular}{|c|l|r|}
\hline No. & Jenis Biaya & Jumlah ( Rp ) \\
\hline 1 & Bensin & 1.200 .000 \\
\hline 2 & Bekal & 500.000 \\
\hline 3 & Biaya Tanaga Kerja 25\% & 1.000 .000 \\
\hline 4 & Pemeliharaan + oli 10\% & 400.000 \\
\hline
\end{tabular}

Sumber: Pengusaha Penangkap Ikan

Sedangkankan biaya modal yang dikeluarkan berupa:
a. Kapal bobot 15 ton
Rp. 250.000.000,-
b. Jaring Pukat
Rp. 150.000.000,-

\section{Potensi Pengembangan Pariwisata Di Sekitar Perairan Pulau Koon}

Kawasan di sekitar perairan pulau Koon memiliki potensi pariwisata yang layak dikembangkan. Gugusan pulau-pulau yang termasuk wilayah kecamatan Pulau Gorom ini memiliki pantai berpasir putih. Perairannya kaya akan ikan dan memiliki keanekaragaman terumbu karang yang sangat indah. Berkumpulnya ikan-ikan untuk melakukan pemijahan di peraiaran Koon ini sungguh merupakan fenomena yang menakjubkan.

Potensi wisata alam lainnya adalah berupa keindahan Danau Soli di Amarsekaru. Danau yang terletak di Pulau Manawoko ini airnya jernih dan asin seperti air laut. Tanaman Pala tumbuh subur dan hampir menutupi sebagian besar pulau yang berukuran agak besar seperti Pulau Gorom dan Pulau Manawoko. Keberadaan hutan tanaman Pala ini potensial untuk dikembangkan menjadi wisata agro.

Selain potensi alamnya, di kawasan ini juga memiliki potensi wisata sejarah dan budaya. Di Pulau Gorom dijumpai peninggalan sejarah berupa Nekara, Kuburan kuno, Batu Sejarah dan Istana Raja Kataloka. Di Pulau Manawoko terdapat bekas Istana Raja Amarsekaru, Makam 
Raja-raja, dan Mesjid Kuno yang masih eksis hingga kini. Potensi budaya masyarakat di sekitar kawasan ini berupa berbagai macam tarian dan upacara adat.

Potensi-potensi wisata yang ada di kawasan ini sayangnya belum dikembangkan dengan baik. Fasilitas wisata berupa penginapan dan rumah makan belum ada di kawasan ini. Pada kajian ini hanya akan membahas pada salah satu unsur pendukung pariwisata yang sudah siap dan bisa dilakukan oleh masyarakat lokal yaitu keterlibatannya dalam penyediaan sarana transportasi wisata laut lokal berupa long boat yang akan melayani wisatawan berkunjung ke objek-objek wisata di sekitar kawasan.

Jika kapal perahu digunakan untuk disewakan atau digunakan sebagai alat transportasi, maka sewa sekali operasi mengelilingi laut sekitar pulau Koon sebesar Rp. 500.000,- dengan jumlah penumpang 1- 4 orang.

Biaya operasi sebesar:
a. Bensin + oli
Rp. 50.000,-
b. Konsumsi
Rp. 50.000,-

Sedangkan biaya modal berupa:
a. Kapal perahu
Rp. 10.000.000,-
b. Speed mesin
Rp. 20.000.000,-

\section{Analisis Proyek}

Dalam menentukan pilihan terhadap proyek yang akan dikembangkan, maka perlu melakukan analisa komperatif antara proyek yang satu dengan proyek lainnya. Dalam pembahasan ini akan dianalisis pengembangan proyek ekowisata bahari dengan penangkapan ikan yang sudah berjalan lama di perairan pulau Koon. Dalam menentukan analisis komperatif antara alternatif satu dengan lainnya ada beberapa aspek yang bisa digunakan sebagai bahan pertimbangan, yang mana meliputi:

\section{Aspek Ekonomi}

Dari aspek ini, pemilihan proyek yang akan dikembangkan dilihat dari manfaat ekonomi yang diterima dan biaya yang akan dikeluarkan untuk pengembangan proyek tersebut atau dengan melihat perbandingan antara manfaat dengan biaya dari masing-masing proyek. Dimana proyek yang dipilih untuk dikembangkan adalah proyek yang ratio benefit cost-nya lebih besar.

Untuk menganalisis pengembangan ekowisata bahari di pulau Koon dengan penangkapan ikan yang telah berlangsung lama, maka sebagai analisis awal hanya akan dibandingkan benefit cost ratio antara penggunaan perahu nelayan untuk menangkap ikan dengan penggunaannya untuk fungsi transportasi wisata. Mengingat di daerah ini belum ada data tentang sarana pariwisata (hotel, restoran) yang disediakan oleh lembaga baik swasta maupun pemerintah, disamping belum adanya data kunjungan ke daerah ini. Selama ini baru ada kapal live a board yang melewati perairan pulau Koon menuju Raja Ampat.

Untuk mengetahui besarnya benefit cost ratio antara kedua alternatif tersebut, maka terlebih dahulu akan dihitung besarnya pendapatan bersih perahu untuk kedua penggunaannya selama setahun. 


\section{1) Penggunaan Perahu untuk menangkap ikan}

a) Pendapatan sekali melaut untuk satu perahu / dua nelayan:

\begin{tabular}{|l|r|r|r|r|r|}
\hline \multirow{2}{*}{ Jenis Ikan } & \multirow{2}{*}{ Harga (Rp) } & \multicolumn{2}{|c|}{ Hasil Tangkapan ( Kg ) } & \multicolumn{2}{l|}{ Pendapatan Kotor ( Rp ) } \\
\cline { 3 - 6 } & & Maksimal & Minimal & Maksimal & Minimal \\
\hline Ikan Tuna & 5.000 & 40 & 25 & 200.000 & 125.000 \\
\hline Ikan Tenggiri & 5.000 & 30 & 10 & 150.000 & 50.000 \\
\hline Ikan Cakalang & 4.000 & 20 & 15 & 80.000 & 60.000 \\
\hline Ikan Bubat & 4.000 & 15 & 5 & 60.000 & 20.000 \\
\hline Ikan & 10.000 & 20 & 10 & 200.000 & 100.000 \\
\hline Jumlah & & 125 & 65 & 690.000 & 355.000 \\
\hline
\end{tabular}

b) Biaya sekali melaut:

Biaya yang dikeluarkan untuk hasil tangkapan maksimal dan minimal adalah sama, dimana besarnya:

\begin{tabular}{|c|l|r|}
\hline No. & Jenis Biaya & Jumlah ( Rp ) \\
\hline 1 & Bensin + oli & 200.000 \\
\hline 2 & Umpan & 150.000 \\
\hline 3 & Bekal & 50.000 \\
\hline 4 & Penyusutan & $71.244,44$ \\
\hline \multicolumn{2}{|c|}{ Jumlah } & $471.244,44$ \\
\hline
\end{tabular}

Perhitungan biaya penyusutan:

Penyusutan $=\frac{\text { Biay a modal }}{\text { Umur Ekonomi }}=\frac{32.060 .000}{5 \times 90}=71.244,44$

c) Pendapatan bersih sekali melaut:

\begin{tabular}{|l|l|l|l|l|}
\hline No. & Hasil Tangkapan & $\begin{array}{l}\text { Pendapatan } \\
\text { Kotor }\end{array}$ & Biaya & Pendapatan Bersih \\
\hline 1 & Maksimal & 690.000 & $471.244,44$ & $218.755,56$ \\
\hline 2 & Minimal & 355.000 & $471.244,44$ & $(116.244,44)$ \\
\hline \multicolumn{2}{|l}{ Jumlah Pendapatan Bersih Rata-rata } & $51.255,56$ \\
\hline
\end{tabular}

d) Pendapatan bersih perahu selama setahun untuk penangkapan ikan:

frekuensi melaut $\mathrm{x}$ pendapatan bersih $=(6 \times 15) \times 51.255,56=$ Rp. 4.613.000,4

e) Net Present Value ( NPV ) dengan discount faktor $10 \%$

$\mathrm{NPV}=$ Procced $\mathrm{x} \sum \mathrm{DF}(10 \%)$

Procced $=$ Pendapatan Bersih + Penyusutan $=4.613 .000,4+6.412 .000$

$=$ Rp. 11.025.000,4

Untuk menentukan besarnya NPV, procced pertahun selama lima tahun dianggap sama. $\sum \operatorname{DF}(10 \%)=3,7907$

$\mathrm{NPV}=11.025 .000,4 \times 3,1907=$ Rp. $41.792 .469,02$

Sedangkan NPV dari seluruh kapal perahu yang ada sebanyak 320 perahu sebesar 41.792.469,02 x $320=$ Rp. 13.373.590.086,4 
f) Benefit Cost Ratio $=$ B/C Ratio $=$ NPV : Io

Io = Investasi awal = biaya modal yang besarnya sama dengan biaya tetap total $=$ Rp. 32.060 .000

Sehingga B/C Ratio $=41.792 .469,02: 32.060 .000=1,3036$

\section{2) Penggunaan perahu untuk alat transportasi wisata}

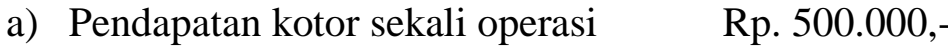

b) Biaya:

- Bensin + oli

Rp. 100.000,-

- Konsumsi Rp. 50.000,-

- Perbaikan Rp. 25.000,-

- Penyusutan Rp. $66.667,-+$

c) Pendapatan bersih
Rp. 241.667,--
Jumlah
Rp. 258.333,-

Perhitungan biaya penyusutan:

Peny usutan $=\frac{\text { Biay a modal }}{\text { Umur ekonomi }}=\frac{30.000 .000}{5 \times 90}=66.667$

d) Pendapatan bersih pertahun dengan operasi sesuai dengan melaut setahun sebanyak 90 kali adalah 90 x $258.333=$ Rp. 23.249.970,-

e) Net Present Value ( NPV ) dengan discount faktor $10 \%$ $\mathrm{NPV}=$ Procced $\mathrm{x} \sum \mathrm{DF}(10 \%)$

Procced $=$ Pendapatan Bersih + Penyusutan $=23.249 .970+6.000 .000,-$ $=$ Rp. 29.249.970,

Untuk menentukan besarnya NPV, procced pertahun selama lima tahun dianggap sama

$\sum \mathrm{DF}(10 \%)=3,7907$

$\mathrm{NPV}=29.249 .970 \times 3,7907=\mathrm{Rp} .88 .133 .661,279$

Sedangkan NPV dari seluruh kapal perahu yang ada sebanyak 320 perahu sebesar 88.133.661,279 x 320 = Rp. 28.202.771.609,2

f) Benefit Cost Ratio $=\mathrm{B} / \mathrm{C}$ Ratio $=$ NPV : Io

Io = Investasi awal = biaya modal yang besarnya sama dengan biaya tetap total $=$ Rp. 30.000 .000

Sehingga B/C Ratio $=88.133 .661,279: 30.000 .000=2,9378$ 
Berdasarkan hasil perhitungan antara penggunaan perahu untuk menangkap ikan dengan penggunaan untuk alat transportasi wisata dapat diringkas sebagai berikut:

\begin{tabular}{|l|l|r|r|}
\hline No. & Keterangan & Tangkap Ikan (Rp) & \multicolumn{1}{l|}{ Transportasi (Rp) } \\
\hline 1 & Pendapatan bersih 1x operasi & $51.255,56$ & $258.333,00$ \\
\hline 2 & Pendapatan bersih pertahun & $4.613 .000,40$ & $23.249 .970,00$ \\
\hline 3 & NPV per-perahu & $41.792 .469,02$ & $88.133 .661,28$ \\
\hline 4 & NPV seluruh perahu & $13.373 .590 .086,40$ & $28.202 .771 .609,20$ \\
\hline 5 & B/C Ratio & 1,3036 & 2,9378 \\
\hline
\end{tabular}

Dari hasil tersebut menunjukkan bahwa pengembangan ekowisata bahari di perairan pulau Koon jauh lebih menguntungkan, dibandingkan kalau potensi yang ada hanya untuk kepentingan penangkapan ikan. Dimana dilihat dari manfaat ekonomi yang diperoleh bila dibandingkan dengan biaya yang dikeluarkan untuk pengembangan ekowisata bahari jauh lebih besar dibandingkan dengan penangkapan ikan. Atau benefit cost ratio pengembangan ekowisata jauh lebih besar dari penangkapan ikan, yaitu 2,9378 berbanding 1.3036 yang besarnya dua kali lipat lebih. Disamping pendapatan riil untuk melaut jauh lebih kecil dari operasi transportasi wisata. Apalagi pengembangan ekowisata bahari bertujuan untuk konservasi terhadap biota laut yang sifatnya berkelanjutan dan dapat melestarikan eksistensi biota laut untuk kepentingan jangka panjang yang nantinya bisa dinikmati oleh generasi penerus akan datang. Ini baru menganalisa dari satu sarana pariwisata yang beroperasi, belum menganalisa sarana pariwisata lainnya yang lebih prospektif yang marginnya lebih besar dari sarana angkutan wisata, sehingga ekowisata bahari ini layak untuk dikembangkan. Tetapi akan terjadi opportunity cost akibat menurunnya pendapatan nelayan setengah dari sebelumnnya, di mana rata-rata opportunity cost yang terjadi selama setahun sebesar NPV seluruh perahu nelayan pertahun $=$ Rp. 13.373.590.086,4 : $5=$ Rp. 2.674.718.017,28. Maka sebagai kompensasinya untuk mengimbangi opportunity cost tersebut, perlu ada kunjungan selama setahun sebesar $=2.674 .718 .017,28: 500.000=5.349,44=5.350$ orang, atau perbulan $=5.350$ $: 12=445,79=446$ orang, atau perhari dengan hari kerja perbulan 25 hari, maka jumlah kunjungan per hari $=(446: 25)$ x $4=71,36=72$ orang. Dengan kunjungan 72 orang per hari ini sudah mampu menutupi kehilangan penghasilan para nelayan untuk setahun. Belum terhitung penghasilan dari para pengusaha sarana pariwisata yang lain, seperti hotel, restoran, warung dan bentuk usaha wisata lainnya. Disamping akan dapat menyediakan lapangan kerja yang lebih luas, sehingga dapat meningkatkan pendapatan.

\section{Aspek Sosial}

Pariwisata merupakan industri yang bersifat "labor Intensive” dan merupakan sektor ekonomi yang banyak menyerap tenaga kerja dibandingkan dengan sektor ekonomi lainnya termasuk sektor pertanian dalam arti luas. Pariwisata mampu menyediakan lapangan kerja yang lebih luas dan dapat membantu pemerintah mengurangi pengangguran yang sifatnya lokal maupun nasional. Sehingga dengan dikembangkan ekowisata bahari ini akan dapat menyerap tenaga kerja lokal dan nasional yang lebih banyak. Sehingga pengembangan ekowisata bahari di perairan pulau Koon layak untuk dikembangkan. Karena akan dapat menyediakan lapangan kerja yang lebih banyak di kecamatan Pulau Gorom. 


\section{Aspek Polilik - Hukum}

Dalam pengembangan pariwisata perlu adanya dukungan yang sifatnya politik baik dari pemerintah maupun dari masyarakat, dan yang terpenting adanya motivasi pelaku bisnis pariwisata untuk berinvestasi di daerah tujuan wisata tersebut. Disamping perlu adanya peraturan dan perundang-undangan yang dapat menjadi payung operasional dalam menjaga stabilitas perkembangan pariwisata. Untuk daerah kabupaten Seram bagian Timur dan khusus perairan pulau Koon yang terdapat di kecamatan Pulau Gorom, sepenuhnya sudah mendapat dukungan dan persetujuan Raja Kataloka dan dipatuhi oleh masyarakatnya, sehingga daerah ini layak untuk dikembangkan. Namun dalam pengelolaan daerah tujuan ekowisata bahari ini perlu adanya aturan yang jelas dalam menghindari terjadinya sesuatu yang tidak diinginkan. Disamping itu sangat diperlukan dukungan pemerintah pusat dalam mendanai pengembangan ekowisata bahari ini, dan juga adanya ulur tangan dari daerah yang pariwisatanya sudah berkembang dalam memberikan konsultasi tentang manajemen pengelolaan objek dan kawasan wisata.

\section{Kendala Yang Dihadapi}

Dalam pengembangan pariwisata tidak sepenuhnya bisa berjalan dengan baik, di mana biasanya dihadapi dengan suatu kendala terutama diperlukan modal yang besar. Untuk pembangunan sarana pariwisata pada daerah pariwisata yang baru dikembangkan biasanya dihadapi dengan sebuah kendala yang berupa masih rendahnya minat investor untuk menginvestasikan dananya, apalagi investor luar daerah. Sehingga pengembangan pariwisata di daerah tersebut ada kecenderungan berjalan agak lambat. Untuk itulah sangat diperlukan peranan pemerintah pusat dalam pengembangannya teutama dapat membantu untuk menyediakan tenaga ahli dan memfasilitasinya serta membangun prasarana pariwisata yang diperlukannya. Disamping diperlukan adanya peranan investor untuk menginvestasikan dananya dalam pembangunan sarana pariwisata serta ikut secara intensif mempromosikan daerah tujuan wisata tersebut.

Untuk pengembangan wisata pada daerah baru biasanya dihadapi dengan kendala rendahnya kualitas sumber daya manusia di daerah tersebut. Sehingga dihadapi dengan sebuah dilematis yang berkaitan dengan recruitment. Apabila tenaga lokal tidak diperkerjakan timbul konflik sosial. Apabila diperkerjakan, karena tidak profesional, maka akan merugikan industri pariwisata. Disamping itu Kendala yang sangat signifikan pengaruhnya terhadap pengembangan pariwisata adalah situasi dan kondisi sosial politik masyarakat daerah yang akan dikembangkan.

\section{KESIMPULAN DAN REKOMENDASI}

Dari hasil pembahasan dapat disimpulkan bahwa pengembangan ekowisata bahari di perairan pulau Koon layak dikembangan yang dapat dilihat dari tiga aspek, yaitu:

1. Aspek ekonomi

Dari aspek ini menunjukkan bahwa benefit cost ratio antara penggunaan perahu untuk penangkapan ikan dengan untuk transportasi wisata adalah lebih besar untuk penggunaan transportasi wisata yaitu 2,9378 berbanding 1.3036 untuk penangkapan ikan. Disamping 
akan memberikan keuntungan yang lebih besar kepada para pelaku wisata lainnya seperti hotel, restoran dan bentuk usaha wisata lainnya.

2. Aspek Sosial

Pariwisata merupakan industri yang bersifat "labor Intensive", dan merupakan sektor ekonomi yang banyak menyerap tenaga kerja dibandingkan dengan sektor ekonomi lainnya, sehingga akan dapat menyediakan lapangan kerja yang lebih luas di kecamatan Pulau Gorom.

3. Aspek Politik-Hukum

Dari aspek ini, pengembangan ekowisata bahari sudah sepenuhnya mendapatkan dukungan Raja Kataloka dan seluruh masyarakat kecamatam Pulau Gorom dan selanjutnya tinggal menunggu dukungan pemerintah serta motivasi para investor untuk membuka usaha sarana wisata di daerah Gorom tersebut.

Walaupun demikian, dalam pengembangan pariwisata biasanya berhadapan dengan berbagai kendala, maka sebagai rekomendasinya:

1. Menerapkan manajemen terpadu dan terbuka dalam pengelolaan objek dan kawasan wisata.

2. Menciptakan sistem keamanan yang terpadu dan melibatkan semua aparat keamanan baik dari unsur formal maupun aparat desa.

3. Perlu adanya aturan yang bersifat representatif dan dapat mewakili semua stakeholder yang terlibat dalam pengembangan dan pengelolaan objek dan kawasan pariwisata.

4. Perlu melakukan promosi secara intensif baik oleh pemerintah maupun oleh pelaku usaha bisnis pariwisata.

\section{UCAPAN TERIMA KASIH}

Ucapan terima kasih disampaikan kepada WWF Indonesia yang telah membiayai penelitian ini, dan Petuanan Raja Kataloka serta masyarakat kecamatan Gorom yang terlibat selama penelitian ini berlangsung.

\section{DAFTAR PUSTAKA}

Balai Pendidikan dan Latihan Pariwisata Bandung. 1990. Tourism Economics. Hand-out. Bina Wisata, Bandung.

Erawan, I Nyoman. 2001. Manajemen Pembangunan Pariwisata Berkelanjutan. Hand-out Magister Kajian Pariwisata, Universitas Udayana, Denpasar.

Mc. Intosh, Robert W. and Goeldner Chales, R. 1984. Tourism, Principles, Practices, Philosophies. Fifth Edition, John Willey \& Sons, Inc, New York.

Jumingan. 2009. Studi Kelayakan Bisnis, PT. Bumi Aksara, Jakarta.

Spillane, James J. 1987. Pariwisata, Sejarah dan Prospeknya. Kanisius, Yogyakarta.

Sutiarso, Moh Agus. 2018. Pengembangan Pariwisata Yang Berkelanjutan Melalui Ekowisata. https://doi.org/10.31219/osf.io/q43ny

Yoeti, Oka A. 2008. Ekonomi Pariwisata. Kompas, Jakarta. 